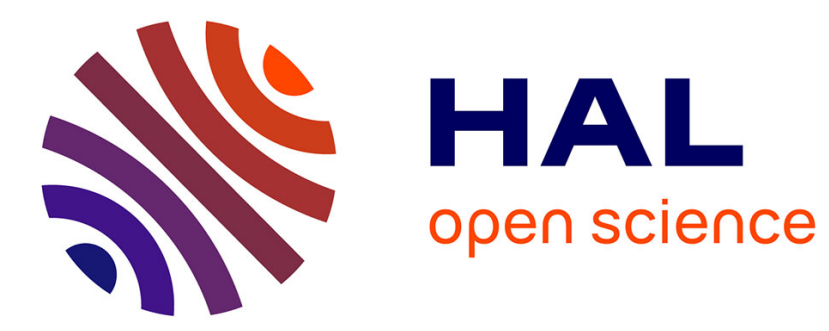

\title{
Fungal communities: relation to resource succession Jean-François Ponge
}

\section{To cite this version:}

Jean-François Ponge. Fungal communities: relation to resource succession. Dighton, J., White, J.F. \& Oudemans, P. The fungal community: its organization and role in the ecosystem, 3rd edition, CRC Press, pp.169-180, 2005, Mycology Series, 978-0824723552. hal-00496986

\section{HAL Id: hal-00496986 https://hal.science/hal-00496986}

Submitted on 2 Jul 2010

HAL is a multi-disciplinary open access archive for the deposit and dissemination of scientific research documents, whether they are published or not. The documents may come from teaching and research institutions in France or abroad, or from public or private research centers.
L'archive ouverte pluridisciplinaire HAL, est destinée au dépôt et à la diffusion de documents scientifiques de niveau recherche, publiés ou non, émanant des établissements d'enseignement et de recherche français ou étrangers, des laboratoires publics ou privés. 


\title{
Fungal communities: relation to resource succession
}

\author{
by Jean-Francois Ponge
}

Museum National d'Histoire Naturelle, CNRS-UMR 8571, 4 avenue du Petit-Chateau, 91800 Brunoy, France, e-mail: jean-francois.ponge@wanadoo.fr

\section{An example of substrate succession: the colonization of pine needles by fungus flora}

Perhaps the most widely studied substrate succession was the successive development of fungal strains and other decomposer organisms at the inside of pine needles, from tree foliage to humified litter. Using litter bags and moist chamber cultures, Kendrick \& Burges (1962) followed the fate of Scots pine needles (Pinus sylvestris L.) in the course of seasons and years and recognized several well-marked steps in the fungal succession. Their study was exemplary inasmuch as they displaced studies on fungal successions from the field of mycology to that of soil ecology. From their results, it appeared that needles, as leaves (Kinkel et al. 1987), were small temporary islands, the inhabitants of which evolved together with their habitat both in space (vertical litter transfer) and time (season, year), while internal resources became progressively depleted. This scheme was reminiscent of patterns and processes observed in the successional development of plant communities by Watt (1947). Other authors described similar sequences in other pine species, pointing on the worldwide occurrence of a few number of more or less pine-specific fungal colonizers succeeding each other in a linear way (Watson et al. 1974, Mitchell \& Millar 1978a, Soma \& Saitô 1979). Other interesting results of pine studies were that the course of fungal succession was strongly influenced by i) the start of colonization when the needle was still living (Mitchell et al. 1976, Mitchell \& Millar 1978a), ii) the nutrient status of the foliage (Lehmann \& Hudson 1977, 
Mitchell and Millar 1978b), iii) climate (Van Maanen et al. 2000, Gourbière et al. 2001), but did not seem to be affected by surface grazing of the needles (McLean et al. 1996).

A more complete pattern, including penetration of pine needles by mycorrhizal fungi and soil micro- and mesofauna, was observed by Ponge (1984, 1985, 1988, 1990, 1991a) by scrutinizing successive layers within a small surface of Scots pine litter $(5 \times 5 \mathrm{~cm})$. The succession of organisms, both microbial and animal, which took place in pine needles, from death of foliage to disappearance in humus, was summarized in Figure 1, taking into account numerous possible short-cuts which were found to occur currently. It should be highlighted that all organisms involved in this successional course mineralized organic matter, through excretory as well as respiratory pathways. In the course of this successional process, which can be considered at first sight as a processing chain sensu Heard (1994), the substrate was observed to change, as long as resources were exploited by successive inhabitants of pine needles, and part of these resources was lost (Berg \& Cortina 1995) or used for the build-up of microbial and animal biomass (Stark 1972, Hasegawa \& Takeda 1996).

The exploitation of internal pine needle tissues was found to begin by the use of cell contents, with weak signs of cell wall destruction. Sections done in needle parts colonized by Lophodermium pinastri (Schrad.) Chev., an ascomyete infecting senescent needles, showed that the fungus was present as hyphae living in the mesophyll tissue, without any penetration of plant cell walls. In the mesophyll tissue, files of cells appeared collapsed, without any starch grains, but cells were still entire, although with a distinct browning of their walls. No profound change occurred in the stele, except a distinct browning of phloem cell walls (Ponge 1984, 1991a). Clearly, the action of the fungus was external and limited to full use of cell wall contents, but browning of cell walls was indicative of its cellulolytic power (Kirk 1983). All needles colonized by this fungus showed typical black diaphragms delineating territories, each occupied by a clone, and black fruit bodies between the epidermis and the hypodermis. At this stage, entire needles or, more often, needle parts, can be occupied by 
another senescence stage fungus, which fructifies once the needle is on the ground: the coelomycete Ceuthospora pinastri (Fr.) Höhn., pycnidial imperfect state of the ascomycete Phacidium lacerum Fr., improperly identified as Fusicoccum bacillare Saccardo \& Penzig by Kendrick \& Burges (1962). Some needles, detached from the tree before reaching maturity, were infected by Lophodermella spp., a stele-invading pathogenic ascomycete (Williamson et al. 1976, Mitchell et al. 1978).

The second main colonizer, Verticicladium trifidum Preuss, conidial state of the ascomycte Desmazierella acicola Lib., was resting as small melanized stroma in ostiola of needles colonized by $L$. pinastri. $D$. acicola was also observed to behave as a first colonizer when needles were still not infected at the time they fell on the ground. When needle parts were colonized by $L$. pinastri or $C$. pinastri, while other parts were still not colonized, then $V$. trifidum was observed to occur first in fungus-free needle sections, later on extending its colonies to the whole needle. In no case $V$. trifidum and L. pinastri were found living together in the same section. Whatever happened before, all needles became progressiveley colonized by $V$. trifidum and the lower layer of entire needles was entirely made of black, softened needles resulting from the activity of this fungus. It has been shown by Kendrick \& Burges (1962) to live several years within the same needle. Several stages were observed during the time this dematiaceous fungus occupied a needle. First, it appeared as thickwalled hyphae growing longitudinally at the inside of resin canals and protoxylem tracheids, but cells from phloem, mesophyll and transfusion tissues were also penetrated altogether (Ponge 1984, 1991a). At this stage, the only tissue which remained free of fungus was the metaxylem, but all other lignified tissues (transfusion tissue, protoxylem) remained intact, with transparent and refringent cell walls (except after previous occupation by L. pinastri). In some needles, starch grains were still present in mesophyll cells, testifying for $V$. trifidum as a first colonizer. In other needles, previous occupancy by $L$. pinastri or $C$. pinastri was attested by the presence of hard, recalcitrant tissues, such as diaphragms or pycnidial walls, respectively. At this stage, blackening of the needles was restricted to the vicinity of stomata, 
where $V$. trifidum filled sub-stomatic chambers with its black stromata. Melanization of pine cells appeared to occur only in stomatal guard cells and nearby hypodermal cells.

The next step was the further development of $V$. trifidum, which formed black stromata in all internal tissues, particularly in the transfusion tissue (Ponge 1985). Tracheids of the transfusion tissue disappeared progressively by lysis, leaving only areolae visible under the phase contrast light microscope. Melanization of pine needles affected the entire hypodermis, the cell walls of which appeared covered internally by thick black deposits, despite the absence of fungal penetration. The late development of $V$. trifidum was thus responsible for blackening and softening of pine needles, which made them palatable to soil saprophagous fauna (Hayes 1963). At this stage, having gained enough energy from the near entire consumption of needle internal tissues, this fungus fructified abundantly, in the form of dense bushes of black conidiophores protruding from stomatal apertures.

At the stage of the late development of $V$. trifidum, needles were actively penetrated by members of soil mesofauna, particularly oribatid mites and enchytraeids. A succession was observed from oribatids to enchytraeids, the latter group invading preferably needles which had been previously excavated by oribatids, which filled them with their excrements (Ponge 1988, 1991a). However, several instances were found of enchytraeids penetrating directly needles previously invaded by $V$. trifidum or even only L. pinastri (Ponge 1984). Defecation by enchytraeids occurred mainly outside pine needles, contrary to oribatid mites, except in most superficial needles where environmental conditions were probably too dry outside pine needles. Within oribatid faeces, pine material appeared to be finely ground by mouth parts of mites and became humified during the intestinal transit, as assessed by optical properties of gut contents. Pine cell walls took a brown and amorphous aspect, with fuzzy contour, indicating strong transformation of both cellulose and lignin (Kilbertus et al. 1976, Saur \& Ponge 1988). Pine material seemed much less transformed in enchytraeid faeces, at least when these animals did not reingest oribatid faeces. Despite abundance and intense activity, 
enchytraeid worms contributed poorly to humification, contrary to oribatids, as this was observed also by Toutain et al. (1982) in beech litter. Penetration by microfauna (nematodes, amoebae) was observed, using holes done by bigger animals. At this stage a bacterial development was prominent within and around collapsed pine needles, following inoculation of microbial germs by soil fauna (Macfadyen 1968, Kilbertus et al. 1976, Touchot et al. 1983). Given size and shape of the cells, these bacterial colonies were supposed to include nitrogen-fixing strains (Ponge 1988).

At this stage, needles became highly friable and most of them were left as small fragments embedded in animal faecal deposits, mostly of enchytraeid origin, which were permeated by dense mycelial webs of mycorrhizal fungi. Dematiaceous (melanized) hyphae of the ascomycete Cenococcum geophilum Fr. and hyaline hyphae of the basidiomycete Hyphodontia sp. were found to arise from monopodial jet-black and coral-like orange-brown mycorrhizae, respectively. Penetration of remaining needles by $C$. geophilum was prominent (Ponge 1988, 1990, 1991a), the fungus passing from its aerial to its submerged form, but resources used by this fungus at the inside of pine needles were not identified, although observations on other humus components concluded to its chitinolytic and cellulolytic activity. Anyhow, the profuse development of mycorrhizal fungi around and within animal faeces and pine needle remains let us to suppose that they used and translocated nutrients released by microbial and animal activity at the inside of pine needles (Bending \& Read 1995). It should be highlighted that the bacterial development registered before this stage seemed to be arrested by mycorrhizal fungi, maybe under the influence of their antibiotic activity (Krywolap \& Casida 1964, Marx 1969, Suay et al. 2000).

\section{Studies on other coniferous species}

Numerous parralels can be found with studies on other conifers. In particular, we must highlight the paramount work done on fir needles (Abies alba Mill.) by Gourbière (1988, 
1990), Gourbière \& Pépin (1984), Gourbière et al. (1985, 1986, 1987, 1989), Gourbière \& Corman (1987), Savoie \& Gourbière (1987, 1988, 1989) and Savoie et al. (1990). They described a fungal succession quite similar to that observed on pine needles. Fir needles were first colonized by Lophodermium piceae (Fckl.) Höhn., a vicariant of L. pinastri, then by Thysanophora penicilloides (Roum.) Kendrick, in place of $V$. trifidum in pines. The segregation between $T$. penicilloides and $L$. piceae was similar to that observed between $V$. trifidum and L. pinastri. However, a prominent difference was that $V$. trifidum was observed to remain in pine needles for several years (Kendrick \& Burges 1962), which allowed it to exploit most internal resources of decaying needles, while $T$. penicilloides (or L. piceae in the absence of further replacement by $T$. penicilloides) was succeeded within a few months by the white rot basidiomycete Marasmius androsaceus (L.: Fr.) Fr. (Gourbière et al. 1987, Gourbière 1990), thus it did not participate to a great extent to the degradation of cell wall material (Gourbière \& Pépin 1984, Gourbière et al. 1986). The penetration of fir needles by rhizomorphs of $M$. androsaceus, which could occur soon after needle fall, was retarded when needles or parts of needles had been previously colonized by L. piceae. This phenomenon was possibly due to the existence of diaphragms, which may act as physical barriers (Ponge 1984). The presence of $M$. androsaceus has been often recorded in pines, too (Lehmann \& Hudson 1977, Mitchell \& Millar 1978a, Soma \& Saitô 1979, Ponge 1985, 1991a, Cox et al. 2001), but its presence in coniferous litter seems to be erratic, probably due to the needle-byneedle colonisation ability of its rhizomorph system (Macdonald \& Cartter 1961, Gourbière \& Corman 1987). The importance of the time of fall for the colonisation of coniferous needles by $M$. androsaceus or other internal fungi ( $T$. penicilloides on fir or $V$. trifidum on pine) was suggested by Ponge (1985) and demonstrated experimentally by Gourbière (1990).

\section{How to explain the observed successions?}

In the course of the above mentioned successional processes of coniferous needle decomposition, food and habitat resources for fungi change to a great extent. The exhaustion 
of cell contents by early colonizers is followed by the differential attack of cellulose-rich then of lignin-rich cell wall material (Savoie \& Gourbière 1988, Cox et al. 2001). In the mean time, fungal, then bacterial biomass, is built-up, which constitutes a new food resource for further colonizers (Berg \& Söderström 1979). These changes are accompanied by an increase in nitrogen (Berg 1988, Hasegawa \& Takeda 1996), water (Virzo de Santo et al. 1993) and metal content (Laskowski \& Berg 1993), while fungal metabolism produces organic acids (Takao 1965, Hintikka et al. 1979, Lapeyrie et al. 1987, Devêvre et al. 1996), melanins (Kuo \& Alexander 1967, Butler et al. 2001) and other metabolites, among them toxins and antibiotics have been widely reported (Wilkins 1948, Krywolap \& Casida 1964, Land \& Hult 1987, Betina 1989). Tannins, terpenes, and other secondary metabolites of coniferous litter exert a selective effect on fungal communities (Black \& Dix 1976, Berg et al. 1980, Lindeberg et al. 1980, Lindeberg 1985), but are progressively degraded by microbial activity (Rai et al. 1988, Lorenz et al. 2000). Thus the internal biochemical environment of coniferous needles varies to a great extent during decomposition, which may interfere with fungal requirements (Savoie et al. 1990). The role of fauna should not be neglected, too. Needle-consuming animals create cavities (Gourbière et al. 1985, Ponge 1991a), comminute and humify organic matter (Ponge 1988, 1991a, 1991b), mobilize nitrogen (Faber 1991) and inoculate microbes (Pherson 1980, Ponge 1984, 1985), thus they condition the inside of pine needles in a different way than fungi themselves. Still controversial, while highly probable, is the selection role of differential grazing on fungal successions (Newell 1984, Klironomos et al. 1992, Bengtsson et al. 1993, McLean et al. 1996). On other substrates than coniferous needles it has been demonstrated that, in the absence of soil fauna, the net result of competition between fungal species was a decrease in the weight loss of the decaying substrate (Rayner et al. 1984, Lussenhop \& Wicklow 1985), while the contrary was observed in the presence of grazing fauna (Lussenhop \& Wicklow 1985). It should not be forgotten, too, that pine material is more or less rapidly, but ineluctably, transformed into animal faeces where other microbial successions can be observed (Van der Drift \& Witkamp 1960, Nicholson et al. 1966, Hanlon 1981, Tajovský et al. 1992). 
We may wonder whether the observed successions are governed by resources, biochemical interference or other interactions between organisms. More probably, a complex of biological and non-biological factors is involved in fungal successions on decaying substrates, as this has been demonstrated in wood (Boddy 2001). Unfortunately, only partial answers can be found in the published literature, given the high degree of specialization now achieved by soil microbiology, and the need for sophisticated methods to address adequately mechanisms. However, some experimental and descriptive studies can throw light on the way by which fungal strains are replaced or cohabit in decaying pine needles. Sometimes, it will be necessary to address other fungal successions, such as those prevailing during wood decay (Levy 1982, Coates \& Rayner 1985, Renvall 1995, Boddy 2001, Hendry et al. 2002) if similar mechanisms can be suspected to occur in decaying needles.

The first result we want to underline is that near all fungal strains involved in the degradation of forest litter are known to have cellulolytic activities (Hudson 1971, Savoie \& Gourbière 1989). In vitro, microfungi from the phylloplane, generally classified as "sugar" fungi (Garrett 1951), prove also able to oxidatively cleave phenolic compounds (Hogg 1966, Haider \& Martin 1967, Rai et al. 1988). However, we have shown that early colonizers of coniferous needles, such as Lophodermium spp., did not attack lignified cell walls (Ponge 1984, Gourbière et al. 1986), such attack being rather performed slowly by secondary (or late primary) colonizers such as V. trifidum and T. penicilloides (Gourbière \& Pépin 1984, Ponge 1988) and, much more rapidly, by non-specific white rots such as $M$. androsaceus and Mycena galopus (Pers.: Fr.) Kummer (Frankland 1984, Ponge 1985, Gourbière \& Corman 1987, Gourbière et al. 1987, Cox et al. 2001). Despite differences in fungal enzymic properties, in particular in the possession of phenoloxydases (Kirk 1983, Hammel 1997), the segregation of fungal colonies on the same needle (Gourbière 1988, Ponge 1991a) and switch-over effects of previous occupants on the fungal succession (Gourbière 1990) point on the importance of biological interactions (Rayner \& Webber 1984, Wicklow 1986, Boddy 
2000). Most of these interactions are based on the defence of the fungal individualistic territory by short-distance biochemical interference (Rayner \& Webber 1984, Wicklow 1992) or, in the case of Lophodermium diaphragms, by physical barriers (Ponge 1984).

The nutrient status of coniferous needles may have an impact on the fungal succession, as this was demonstrated by Lehmann \& Hudson (1977) and Mitchell \& Millar (1978b): the application of lime or urea to decaying litter favoured the more nutrient-demanding ascomycetes (early colonizers) and disfavoured less-demanding white rot basidiomycetes (late colonizers), while the decomposition rate was increased (Sanchez 2001). This could indicate that early colonizers are potentially able to fulfill the whole decomposition process but lack nutrients to i) exploit existing resources, ii) antagonize better-equipped fungi. These, and more especially cellulolytic basidiomycetes, are able to derive micro- and macronutrients from the degradation of recalcitrant compounds such as cell walls and tanninprotein complexes (Saitô 1965, Entry et al. 1991), starting with the production of low energycost oxalic acid, non-enzymatically active during early stages of cellulose degradation (Hintikka 1970, Schmidt et al. 1981), followed by high energy-cost enzymic production at later stages of degradation (Kirk 1983, Hammel 1997).

All these results point on biological processes as key factors that determine fungal successions at the inside of decaying coniferous needles. Colonization and dispersal are two fundamental steps of the development of fungal communities, at least from the point of view of the individualistic mycelium (Ogawa 1977, Rayner et al. 1984, Dowson et al. 1986, Dahlberg \& Stenlid 1994, Gourbière \& Gourbière 2002). Intra- and inter-specific competition contribute in turn to the shape of the community, by restricting each fungus both in space and time (Rayner \& Webber 1984, Boddy 2000, 2001). Such interactive processes, including founder effects, i.e. the advantage given to the first invader, have been demonstrated to play an important role in plant successions (Connell \& Slatyer 1977, Finegan 1984, Pickett et al. 1987, Grime 1987, McCook 1994) as well as in fungal successions (Tribe 1966, Coates \& 
Rayner 1985, Frankland 1992, Renvall 1995, Niemelä et al. 1995, Hendry et al. 2002). Gourbière et al. (1999) modelized the persistence and the extinction of a fungal species colonizing a number of discrete resource units, and applied this model to the experimental colonization of fir needles. Their results showed that the model, the parameters of which were determined by the experiment, accounted for the observed distribution of needles colonized in the field by the same fungus. Later on, they extended their model to two competing species, demonstrating that both species could coexist even in the absence of any trade-off between competitive and colonization abilities, but that the outcome of competition depended on a founder effect (Gourbière \& Gourbière 2002). Recent discoveries did not prove unequivocally that biological traits of individuals/species and their interactions are the only reasons for fungal successions, but rather that biological patterns and processes play a decisive role in the way by which species are assembled both in space and time, as this has been recognized for a long time in plant communities (Watt 1947).

\section{Conclusion: a story of coniferous needles}

A hypothetical scheme, which explains most of the variation observed in the fungal colonisation of coniferous needles can be drawn, on the basis of present knowledge. Colonization of the inside of needles starts by the penetration of a restricted array of fungal strains which are able to withstand the biochemical environment of coniferous foliage (phenols, terpenes, carbon dioxide). This early colonisation occurs while needles are still attached on the tree, during the senescence stage. This step can be precociously achieved when fungal pathogens penetrate the needle, which causes its premature fall. Once fallen on the ground, the development of these early colonizers goes further, at the inside of territories delineated by barriers (biochemical, physical) created by each individualistic mycelium, until reproduction organs are produced. As far as original toxic compounds are degraded, and fungal defences are alleviated (for instance following full use of energy for fructification), colonisation may progress through the development of other, less specialized strains, 
already present as resting organs at the needle surface or able to transport energy from needle to needle through rhizomorphs. Litter-dwelling animals play an active role in the dissemination of fungal spores and, possibly if not clearly demonstrated, by stimulating or impeding the development of some fungal strains, according to their feeding preferences.

\section{References}

Bending, G.D. \& Read, D.J. 1995. The structure and function of the vegetative mycelium of ectomycorrhizal plants. V. Foraging behaviour and translocation of nutrients from exploited litter. The New Phytologist 130: 401-409.

Bengtsson, G., Hedlund, K. \& Rundgren, S. 1993. Patchiness and compensatory growth in a fungus-Collembola system. Oecologia 93: 296-302.

Berg, B. 1988. Dynamics of nitrogen $\left({ }^{15} \mathrm{~N}\right)$ in decomposing Scots pine (Pinus sylvestris) needle litter. Long-term decomposition in a Scots pine forest VI. Canadian Journal of Botany 66: 1539-1546.

Berg, B. \& Cortina, J. 1995. Nutrient dynamics in some decomposing leaf and needle litter types in a Pinus sylvestris forest. Scandinavian Journal of Forest Research 10: 1-11.

Berg, B., Hannus, K., Popoff, T. \& Theander, O. 1980. Chemical components of Scots pine needles and needle litter and inhibition of fungal species by extractives. In: Structure and function of northern coniferous forests. An ecosystem study, ed. Persson, T. Ecological Bulletins 32: 391-400.

Berg, B. \& Söderström, B. 1979. Fungal biomass and nitrogen in decomposing Scots pine needle litter. Soil Biology and Biochemistry 11: 339-341.

Betina, V. 1989. Mycotoxins: chemical, biological and environmental aspects. Elsevier Science, New York, New York.

Black, R.L.B. \& Dix, N.J. 1976. Spore germination and germ hyphal growth of microfungi from litter and soil in the presence of ferulic acid. Transactions of the British Mycological Society 66: 305-311. 
Boddy, L. 2000. Interspecific combative interactions between wood-decaying basidiomycetes. FEMS Microbiology Ecology 31: 185-194.

Boddy, L. 2001. Fungal community ecology and wood decomposition processes in angiosperms: from standing tree to complete decay of coarse woody debris. Ecological Bulletins 49: 43-56.

Butler, M.J., Day, A.W., Henson, J.M. \& Money, N.P. 2001. Pathogenic properties of fungal melanins. Mycologia 93: 1-8.

Coates, D. \& Rayner, A.D.M. 1985. Fungal population and community development in cut beech logs. III. Spatial dynamics, interactions and strategies. The New Phytologist 101: 183-198.

Connell, J.H. \& Slatyer, R.O. 1977. Mechanisms of succession in natural communities and their role in community stability and organization. The American Naturalist 111: 11191144

Cox, P., Wilkinson, S.P. \& Anderson, J.M. 2001. Effects of fungal inocula on the decomposition of lignin and structural polysaccharides in Pinus sylvestris litter. Biology and Fertility of Soils 33: 246-251.

Dahlberg, A. \& Stenlid, J. 1994. Size, distribution and biomass of genets in populations of Suillus bovinus (L.: Fr.) Roussel revealed by somatic incompatibility. The New Phytologist 128: 225-234.

Devêvre, O., Garbaye, J. \& Botton, B. 1996. Release of complexing organic acids by rhizosphere fungi as a factor in Norway spruce yellowing in acidic soils. Mycological Research 100: 1367-1374.

Dowson, C.G., Rayner, A.D.M. \& Boddy, L. 1986. Outgrowth patterns of mycelial cordforming basidiomycetes from and between woody resource units in soil. Journal of General Microbiology 132: 203-211.

Entry, J.A., Rose, C.L. \& Cromack, K.Jr. 1991. Litter decomposition and nutrient release in ectomycorrhizal mat soils of a Douglas fir ecosystem. Soil Biology and Biochemistry 23: $285-290$. 
Faber, J.H. 1991. The interaction of Collembola and mycorrhizal roots in nitrogen mobilization in a Scots pine forest soil. In: Advances in management and conservation of soil fauna, eds. Veeresh, G.K., Rajagopal, D. \& Viraktamath, C.A. Oxford, UK and IBH Publishing Company, New Delhi, India, 507-515.

Finegan, B. 1984. Forest succession. Nature 312: 109-114.

Frankland, J.C. 1984. Autecology and the mycelium of a woodland litter decomposer. In: The ecology and physiology of the fungal mycelium, eds. Jennings, D.H. \& Rayner, A.D.M.. Cambridge University Press, Cambridge, UK, 241-260.

Frankland, J.C. 1992. Mechanisms in fungal succession. In: The fungal community, its organization and role in the ecosystem, $2^{\text {nd }}$ ed., eds. Carroll, G.C. \& Wicklow, D.T. Marcel Dekker, New York, New York, 383-401.

Garrett, S.D. 1951. Ecological groups of soil fungi: a survey of substrate relationships. The New Phytologist 50: 149-166.

Gourbière, F. 1988. Structure spatio-temporelle de la mycoflore des premiers stades de décomposition des aiguilles d'Abies alba. Soil Biology and Biochemistry 20: 453-458.

Gourbière, F. 1990. Structure spatio-temporelle de la mycoflore décomposant les aiguilles d'Abies alba: place de Marasmius androsaceus. Soil Biology and Biochemistry 22: 563-569.

Gourbière, F. \& Corman, A. 1987. Décomposition des aiguilles d'Abies alba: hétérogénéité du substrat et de la mycoflore, rôle de Marasmius androsaceus. Soil Biology and Biochemistry 19: 69-75.

Gourbière, F., Gourbière, S., Van Maanen, A., Vallet, G. \& Auger, P. 1999. Proportion of needles colonized by one fungal species in coniferous litter: the dispersal hypothesis. Mycological Research 103: 353-359.

Gourbière, F., Lions, J.C. \& Pépin, R. 1985. Activité et développement d'Adoristes ovatus (C.L. Koch, 1839) (Acarien, Oribate) dans les aiguilles d'Abies alba Mill. Relations avec la décomposition et les microflores fongiques. Revue d'Écologie et de Biologie du Sol 22: 57-73. 
Gourbière, F. \& Pépin, R. 1984. Microscopie de la mycoflore des aiguilles de sapin (Abies alba). I. Thysanophora penicilloides. Canadian Journal of Botany 62: 1537-1544.

Gourbière, F., Pépin, R. \& Bernillon, D. 1986. Microscopie de la mycoflore des aiguilles de sapin (Abies alba). II. Lophodermium piceae. Canadian Journal of Botany 64: 102107.

Gourbière, F., Pépin, R. \& Bernillon, D. 1987. Microscopie de la mycoflore des aiguilles de sapin (Abies alba). III. Marasmius androsaceus. Canadian Journal of Botany 65: 131136.

Gourbière, F., Pépin, R. \& Bernillon, D. 1989. Microscopie de la mycoflore des aiguilles de sapin blanc (Abies alba). IV. Décomposition de la cuticule, de I'hypoderme et de l'épiderme. Canadian Journal of Botany 67: 933-939.

Gourbière, F., Van Maanen, A. \& Debouzie, D. 2001. Associations between three fungi on pine needles and their variation along a climatic gradient. Mycological Research 105: 1101-1109.

Gourbière, S. \& Gourbière, F. 2002. Competition between unit-restricted fungi: a metapopulation model. Journal of Theoretical Biology 217: 351-368.

Grime, J.P. 1987. Dominant and subordinate components of plant communities: implications for succession, stability and diversity. In: Colonization, succession and stability, eds. Gray, A.J., Crawley, M.J. \& Edwards, P.J. Blackwell, Oxford, UK, 413-428.

Haider, K. \& Martin, J.P. 1967. Synthesis and transformation of phenolic compounds by Epicoccum nigrum in relation to humic acid formation. Soil Science Society of America Proceedings 31: 766-772.

Hammel, K.E. 1997. Fungal degradation of lignin. In: Driven by nature: plant litter quality and decomposition, eds. Cadish, G. \& Giller, K.E. CAB International, Wallingford, UK, 3345.

Hanlon, R.D.G. 1981. Some factors influencing microbial growth on soil animal faeces. II. Bacterial and fungal growth on soil animal faeces. Pedobiologia 21: 264-270. 
Hasegawa, M. \& Takeda, H. 1996. Carbon and nutrient dynamics in decomposing pine needle litter in relation to fungal and faunal abundances. Pedobiologia 40: 171-184.

Hayes, A.J. 1963. Studies on the feeding preferences of some phthiracarid mites (Acari: Oribatidae). Entomologia Experimentalis et Applicata 6: 241-256.

Heard, S.B. 1994. Processing chain ecology: resource condition and interspecific interactions. Journal of Animal Ecology 63: 451-464.

Hendry, S.J., Boddy, L. \& Lonsdale, D. 2002. Abiotic variables effect differential expression of latent infections in beech (Fagus sylvatica). The New Phytologist 155: 449-460.

Hintikka, V. 1970. Studies on white-rot humus formed by higher fungi in forest soils. Communicationes Instituti Forestalis Fenniae 69.2.

Hintikka, V., Korhonen, K. \& Näykki, O. 1979. Occurrence of calcium oxalate in relation to the activity of fungi in forest litter and humus. Karstenia 19: 58-64.

Hogg, B.M. 1966. Micro-fungi on leaves of Fagus sylvatica. II. Duration of survival, spore viability and cellulolytic activity. Transactions of the British Mycological Society 49: 193-204.

Hudson, H.J. 1971. The development of the saprophytic fungal flora as leaves senesce and fall. In: Ecology of leaf surface micro-organisms, eds. Preece, T.F. \& Dickinson, C.H. Academic Press, New York, New York, 447-455.

Kendrick, W.B. \& Burges, A. 1962. Biological aspects of the decay of Pinus silvestris leaf litter. Nowa Hedwigia 4: 313-342 + 14 inlet plates.

Kilbertus, G., Rohr, R. \& Mangenot, F. 1976. Étude ultrastructurale de quelques étapes de la biodégradation dans la nature du tissu lignifié de Pinus nigra Arn. subsp. laricio (Poir.) Maire. Holzforschung 30: 156-164.

Kinkel, L.L., Andrews, J.H., Berbee, F.M. \& Nordheim, E.V. 1987. Leaves as islands for microbes. Oecologia 71: 405-408.

Kirk, T.K. 1983. Degradation and conversion of lignocelluloses. In: The filamentous fungi. IV. Fungal technology, eds. Smith, J.E., Berry, D.R. \& Kristiansen, B. Edward Arnold, London, UK, 266-295. 
Klironomos (J.N.), Widden (P.) \& Deslandes (I.), 1992. Feeding preferences of the collembolan Folsomia candida in relation to microfungal successions on decaying litter. Soil Biology and Biochemistry 24: 685-692.

Krywolap, G.N. \& Casida, L.E.Jr. 1964. An antibiotic produced by the mycorrhizal fungus Cenococcum graniforme. Canadian Journal of Microbiology 10: 365-370.

Kuo, M.J. \& Alexander, M. 1967. Inhibition of the lysis of fungi by melanins. Journal of Bacteriology 94: 624-629.

Land, C.J. \& Hult, K. 1987. Mycotoxin production by some wood-associated Penicillium spp. Letters in Applied Microbiology 4: 41-44.

Lapeyrie, F., Chilvers, G.A. \& Bhem, C.A. 1987. Oxalic acid synthesis by the mycorrhizal fungus Paxillus involutus (Batsch. Ex Fr.) Fr. The New Phytologist 106: 139-146.

Laskowski, R. \& Berg, B. 1993. Dynamics of some mineral nutrients and heavy metals in decomposing forest litter. Scandinavian Journal of Forest Research 8: 446-456.

Lehmann, P.F. \& Hudson, H.J. 1977. The fungal succession on normal and urea-treated pine needles. Transactions of the British Mycological Society 68: 221-228.

Levy, J.F. 1982. The place of basidiomycetes in the decay of wood in contact with the ground. In: Decomposer basidiomycetes: their biology and ecology, eds. Frankland, J.C., Hedger, J.N. \& Swift, M.J. Cambridge University Press, Cambridge, UK, 161178.

Lindeberg, G. 1985. Stimulation of some litter-decomposing basidiomycetes by shikimic acid. Physiologia Plantarum 65: 9-14.

Lindeberg, G., Lindeberg, M., Lundgren, L., Popoff, T. \& Theander, O. 1980. Stimulation of litter-decomposing basidiomycetes by flavonoids. Transactions of the British Mycological Society 75: 455-459.

Lorenz, K., Preston, C.M., Raspe, S., Morrison, I.K. \& Feger, K.H. 2000. Litter decomposition and humus characteristics in Canadian and German spruce ecosystems: information from tannin analysis and ${ }^{13} \mathrm{C}$ CPMAS NMR. Soil Biology and Biochemistry 32: 779792. 
Lussenhop, J. \& Wicklow, D.T. 1985. Interaction of competing fungi with fly larvae. Microbial Ecology 11: 175-182.

Macdonald, J.A. \& Cartter, M.A. 1961. The rhizomorphs of Marasmius androsaceus Fries. Transactions of the British Mycological Society 44: 72-78.

Macfadyen, A. 1968. The animal habitat of soil bacteria. In: The ecology of soil bacteria, eds. Gray, T.R.G. \& Parkinson, D. Liverpool University Press, Liverpool, UK, 66-76.

McCook, L.J. 1994. Understanding ecological community succession: causal models and theories, a review. Vegetatio 110: 115-147.

McLean, M.A., Kaneko, N. \& Parkinson, D. 1996. Does selective grazing by mites and collembola affect litter fungal community structures? Pedobiologia 40: 97-105.

Marx, D.H. 1969. The influence of ectotrophic mycorrhizal fungi on the resistance of pine roots to pathogenic infections. I. Antagonism of mycorrhizal fungi to root pathogenic fungi and soil bacteria. Phytopathology 59: 153-163.

Mitchell, C.P. \& Millar, C.S. 1978a. Mycofloral successions on corsican pine needles colonized on the tree by three different fungi. Transactions of the British Mycological Society $71: 303-317$.

Mitchell, C.P. \& Millar, C.S. 1978b. Effect of lime and urea on decomposition of senescent corsican pine needles colonized by Lophodermium pinanstri. Transactions of the British Mycological Society 71: 375-381.

Mitchell, C.P., Millar, C.S. \& Williamson, B. 1978. The biology of Lophodermella conjuncta Darker on Corsican pine needles. European Journal of Forest Pathology 8: 108-118.

Mitchell, C.P., Williamson, B. \& Millar, C.S. 1976. Hendersonia acicola on pine needles infected by Lophodermella sulcigena. Euroepan Journal of Forest Pathology 6: 92102.

Newell, K. 1984. Interaction between two decomposer basidiomycetes and a collembolan under sitka spruce: grazing and its potential effects on fungal distribution and litter decomposition. Soil Biology and Biochemistry 16: 235-239. 
Nicholson, P.B., Bocock, K.L. \& Heal, O.W. 1966. Studies on the decomposition of the faecal pellets of a millipede (Glomeris marginata (Villers)). Journal of Ecology 54: 755-766.

Niemelä, T., Renvall, P. \& Penttilä, R. 1995. Interactions of fungi at late stages of wood decomposition. Annales Botanici Fennici 32: 141-152.

Ogawa, M. 1977. Ecology of higher fungi in Tsuga diversifolia and Betula ermani-Abies mariesii forests of subalpine zone. Transactions of the Mycological Society of Japan 18: 1-19.

Pherson, D.A. 1980. The role of invertebrates in the fungal colonization of leaf litter. In: Soil biology as related to land use practices, ed. Dindal, D.L. Environmental Protection Agency, Washington, D.C., 604-615.

Pickett, S.T.A., Collins, S.L. \& Armesto, J.J. 1987. A hierarchical consideration of causes and mechanisms of succession. Vegetatio 69: 109-114.

Ponge, J.F. 1984. Étude écologique d'un humus forestier par l'observation d'un petit volume, premiers résultats. I. La couche $L_{1}$ d'un moder sous pin sylvestre. Revue d'Écologie et de Biologie du Sol 21: 161-187.

Ponge, J.F. 1985. Étude écologique d'un humus forestier par l'observation d'un petit volume.

II. La couche $\mathrm{L}_{2}$ d'un moder sous Pinus sylvestris. Pedobiologia 28: 73-114.

Ponge, J.F. 1988. Étude écologique d'un humus forestier par l'observation d'un petit volume.

III. La couche $F_{1}$ d'un moder sous Pinus sylvestris. Pedobiologia 31: 1-64.

Ponge, J.F. 1990. Ecological study of a forest humus by observing a small volume. I. Penetration of pine litter by mycorrhizal fungi. European Journal of Forest Pathology 20: $290-303$.

Ponge, J.F. 1991a. Succession of fungi and fauna during decomposition of needles in a small area of Scots pine litter. Plant and Soil 138: 99-113.

Ponge, J.F. 1991b. Food resources and diets of soil animals in a small area of Scots pine litter. Groderma 49: 33-62. 
Rai, B., Upadhyay, R.S. \& Srivastava, A.K. 1988. Utilization of cellulose and gallic acid by litter inhabiting fungi and its possible implication in litter decomposition of a tropical deciduous forest. Pedobiologia 32: 157-165.

Rayner, A.D.M., Coates, D., Ainsworth, A.M., Adams, T.J.H., Williams, E.N.D. \& Todd, N.K. 1984. The biological consequences of the individualistic mycelium. In: The ecology and physiology of the fungal mycelium, eds. Jennings, D.H. \& Rayner, A.D.M. Cambridge University Press, Cambridge, UK, 509-540.

Rayner, A.D.M. \& Webber, J.F. 1984. Interspecific mycelial interactions. An overview. In: The ecology and physiology of the fungal mycelium, eds. Jennings, D.H. \& Rayner, A.D.M. Cambridge University Press, Cambridge, UK, 383-417.

Renvall, P. 1995. Community structure and dynamics of wood-rotting basidiomycetes on decomposing conifer trunks in northern Finland. Karstenia 35: 1-51.

Saitô, T. 1965. Coactions between litter-decomposing hymenomycetes and their associated microorganisms during decomposition of beech litter. Science Reports of the Tôhoku University, Series IV, Biology 31: 255-273.

Sanchez, F.G. 2001. Loblolly pine needle decomposition and nutrient dynamics as affected by irrigation, fertilization, and substrate quality. Foest Ecology and Management 152: 85-96.

Saur, E. \& Ponge, J.F. 1988. Alimentary studies on the collembolan Paratullbergia callipygos using transmission electron microscopy. Pedobiologia 31: 355-379.

Savoie, J.M., Bernillon, D. \& Gourbière, F. 1990. Cellulase activities in senescent coniferous needles and in needle litter naturally colonized by various fungi. FEMS Microbiology Ecology 73: 175-180.

Savoie, J.M. \& Gourbière, F. 1987. The role of polysaccharidase enzymes in the organisation of the fungal communities of a forest leaf litter. Food Hydrocolloids 1: 519-520.

Savoie, J.M. \& Gourbière, F. 1988. Équipement enzymatique des champignons dégradant les aiguilles d'Abies alba Mill. Revue d'Écologie et de Biologie du Sol 25: 149-160. 
Savoie, J.M. \& Gourbière, F. 1989. Decomposition of cellulose by the species of the fungal succession degrading Abies alba needles. FEMS Microbiology Ecology 62: 307-314.

Schmidt, C.J., Whitten, B.K. \& Nicholas, D.D. 1981. A proposed role for oxalic acid in nonenzymatic wood decay by brown-rot fungi. Proceedings of the Annual Meetings of the American Wood-Preservers Association 77: 157-163.

Soma, K. \& Saitô, T. 1979. Ecological studies of soil organisms with references to the decomposition of pine needles. I. Soil macrofaunal and mycofloral surveys in coastal pine plantations. Revue d'Écologie et de Biologie du Sol 16: 337-354.

Stark, N. 1972. Nutrient cycling pathways and litter fungi. BioScience 22: 355-360.

Suay, I., Arenal, F., Asenio, F., Basilio, A., Cabello, M., Diez, M.T., Garcia, J.B., Gonzalez del Val, A., Gorrochategui, J., Hernandez, P., Pelaez F., \& Vicente, M. F. 2000. Screening of basidiomycetes for antimicrobial activities. Antonie van Leeuwenhoek 78: 129-139.

Tajovský, K., Šantrůčková, H., Háněl, L., Balík, V. \& Lukešová, A. 1992. Decomposition of faecal pellets of the millipede Glomeris hexasticha (Diplopoda) in forest soil. Pedobiologia 36: 146-158.

Takao, S. 1965. Organic acid production by basidiomycetes. I. Screening of acid-producing strains. Applied Microbiology 13: 732-737.

Touchot, F., Kilbertus, G. \& Vannier, G. 1983. Rôle d'un collembole (Folsomia candida) au cours de la dégradation des litières de charme et de chêne, en présence ou en absence d'argile. In: New trends in soil biology, eds. Lebrun, P., André, H.M., De Medts, A., Grégoire-Wibo, C. \& Wauthy, G. Université Catholique de Louvain, Louvain-la-Neuve, Belgium, 269-280.

Toutain, F., Villemin, G., Albrecht, A. \& Reisinger, O. 1982. Étude ultrastructurale des processus de biodégradation. II. Modèle enchytréides-litière de feuillus. Pedobiologia 23: $145-156$.

Tribe, H.T. 1966. Interactions of soil fungi on cellulose film. Transactions of the British Mycological Society 49: 457-466. 
Van der Drift, J. \& Witkamp, M. 1960. The significance of the break-down of oak litter by Enoicyla pusilla. Archives Néerlandaises de Zoologie 13: 486-492.

Van Maanen, A., Debouzie, D. \& Gourbière, F. 2000. Distribution of three fungi colonising fallen Pinus sylvestris needles along altitudinal transects. Mycological Research 104: 1133-1138.

Virzo de Santo, A., Berg, B., Rutigliano, F.A., Alfani, A. \& Fioretto, A. 1993. Factors regulating early-stage decomposition of needle litters in five different coniferous forests. Soil Biology and Biochemistry 25: 1423-1433.

Watson, E.S., McClurkin, D.C. \& Huneycutt, M.B. 1974. Fungal succession on loblolly pine and upland hardwood foliage and litter in North Mississippi. Ecology 55: 1128-1134.

Watt, A.S. 1947. Pattern and process in the plant community. Journal of Ecology 35: 1-22.

Wicklow, D.T. 1986. The role of competition in the structuring of fungal communities. In: Perspectives in microbial ecology, eds. Megusar, F. \& Gantar, M. Slovene Society for Microbiology, Ljubljana, Slovenia, 131-137.

Wicklow, D.T. 1992. Interference competition. In: The fungal community, its organization and role in the ecosystem, $2^{\text {nd }}$ ed., eds. Carroll, G.C. \& Wicklow, D.T. Marcel Dekker, New York, New York, 265-274.

Wilkins, W.H. 1948. Investigation into the production of bacteriostatic substances by fungi. Preliminary examination of the ninth 100 species, all basidiomycetes. British Journal of Experimental pathology 29: 364-366.

Williamson, B., Mitchell, C.P. \& Millar, C.S. 1976. Histochemistry of Corsican pine needles infected by Lophodermella sulcigena (Rostr.) v.Höhn. Annals of Botany 40: 281-288. 


\section{Legends of figures}

Fig. 1. Succession of organisms observed during the decomposition of Scots pine needles (after Ponge, 1999). $\mathrm{m}=$ mineralization 


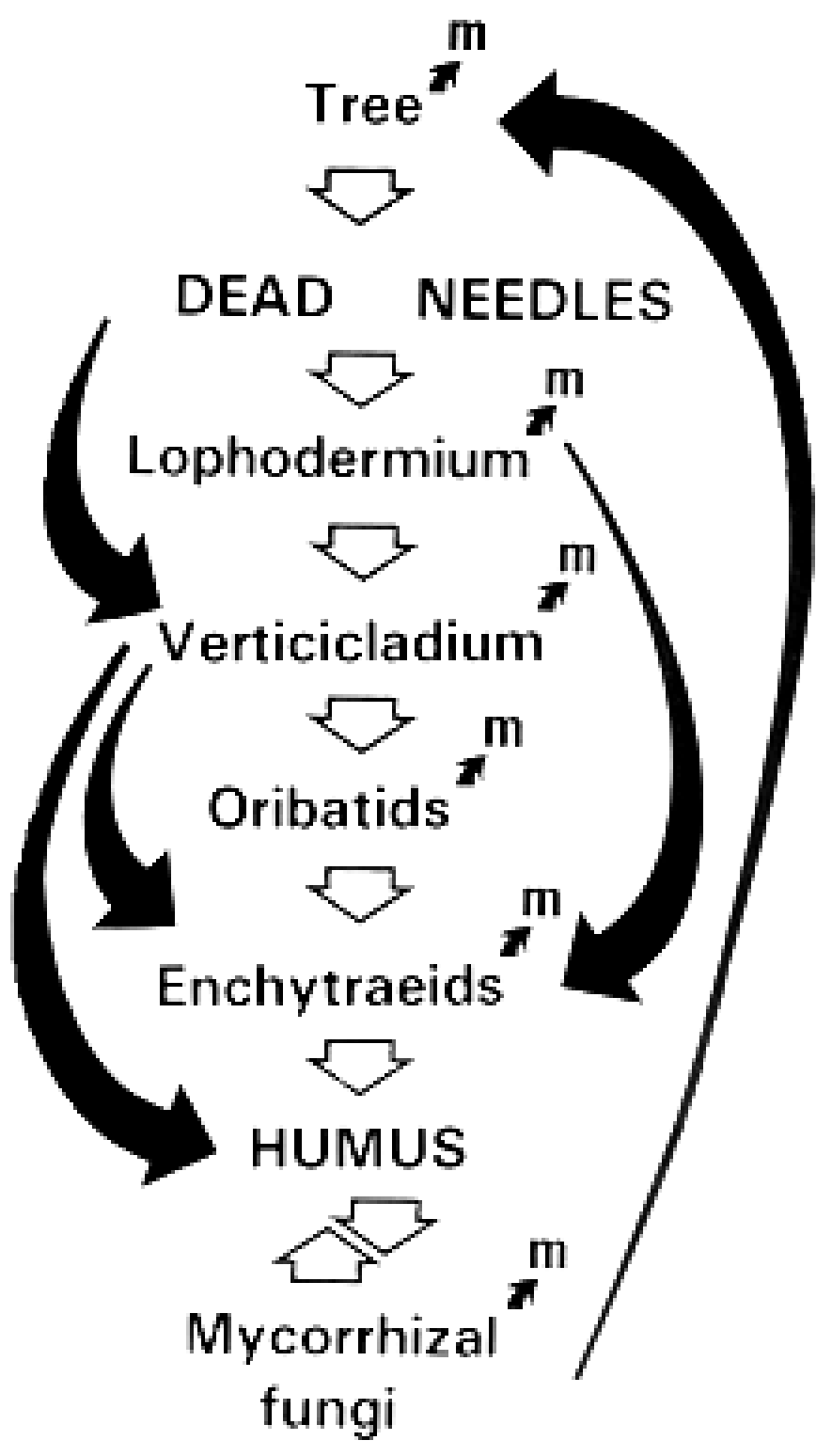

Fig. 1 